Kajian Jurnalisme

ISSN 2549-0559 (cetak) ISSN 2549-1946 (online)

Volume 01 Nomor 02 Tahun 2018

\title{
Konstruksi Realitas Wartawan Pikiran Rakyat Mengenai Pengarusutamaan Isu Lingkungan
}

\author{
Dina Aqmarina Yanuary dan Gumgum Gumilar \\ Program Studi Ilmu Jurnalistik, Fakultas Ilmu Komunikasi, Universitas Padjadjaran \\ Email: dinayanuary@gmail.com
}

\begin{abstract}
This paper discusses the knowledge, motives, and experiences of reporters in building environmental issues and interpreting the effects of environmental problems as headlines. The subjects of this research were five reporters of Pikiran Rakyat. This research used qualitative research method with using the phenomenology study. The data in this research was obtained through in-depth interviews, participatory observation, and document analysis. The results of the study showed that before becoming a journalist, the informants to obtain information about environmental issues through the mass media and direct experience. After being the journalists, they also made adjustments to the socio-cultural world of journalism, such as their informant, another journalist, and location reporting.xperience made informants have various motives for mainstreaming environmental issues. After making the adjustment and gain motives, informants make environmental issues into the straight news that made the headlines by the editor. Based on that, the informants have meaning on environmental issues in the headlines, among others: environmental issues are critically important, must be accounted for, environmental issues have become a major concern, high-value proximity, and have an impact.
\end{abstract}

Key Words: Environmental issues, headline, mainstream, phenomenology, reporter

\begin{abstract}
Abstrak
Makalah ini membahas pengetahuan, motif, dan pengalaman wartawan dalam membangun isu-isu lingkungan, dan menafsirkan efek dari masalah lingkungan sebagai berita utama. Subjek penelitian ini adalah lima wartawan Pikiran Rakyat. Penelitian ini menggunakan metode penelitian kualitatif dengan menggunakan studi fenomenologi. Data dalam penelitian ini diperoleh melalui wawancara mendalam, observasi partisipatif, dan analisis dokumen. Hasil penelitian menunjukkan bahwa sebelum menjadi jurnalis, informan mendapatkan informasi tentang masalah lingkungan melalui media massa dan pengalaman langsung. Setelah menjadi jurnalis, mereka juga membuat penyesuaian dengan dunia sosial-budaya jurnalisme, seperti informan mereka, jurnalis lain, dan pelaporan lokasi. Pengalaman membuat informan memiliki berbagai motif untuk mengarusutamakan masalah lingkungan. Setelah melakukan penyesuaian dan mendapatkan motif, informan membuat isu lingkungan menjadi berita langsung yang menjadi berita utama oleh editor. Berdasarkan hal tersebut, para informan memiliki makna pada isu-isu lingkungan dalam tajuk utama, antara lain: masalah lingkungan sangat penting, harus dipertanggungjawabkan, masalah lingkungan telah menjadi perhatian utama, kedekatan bernilai tinggi, dan berdampak.
\end{abstract}

Kata Kunci: Isu lingkungan, headline, pengarusutamaan, fenomenologi, reporter http://jurnal.unpad.ac.id/kajian-jurnalisme 
Kajian Jurnalisme

ISSN 2549-0559 (cetak) ISSN 2549-1946 (online)

Volume 01 Nomor 02 Tahun 2018

\section{Pendahuluan}

Pada September 2015, Indonesia mengalami musim kemarau. Beragam permasalahan terjadi, seperti pembakaran hutan di Riau, gunung-gunung yang terbakar di sekitar Jawa Barat, minimnya air bersih, matinya jalur air PDAM, panen yang gagal, keringnya sungai-sungai, dan masih banyak permasalahan lainnya. Beragam media massa membahas kejadian tersebut, tapi ratarata hanya membahas kejadian yang sama, yakni pembakaran hutan di Riau. Peneliti mengamati, jarang ada media massa yang membahas persoalan lingkungan secara terus menerus. Dari sekian banyak koran nasional dan regional di Indonesia, hanya ada dua koran yang membahas persoalan lingkungan secara terus menerus, yakni Kompas dan Pikiran Rakyat.

Dalam pengamatan peneliti, meskipun Pikiran Rakyat tidak memiliki rubrik khusus lingkungan, tapi secara rutin Pikiran Rakyat mengangkat isu lingkungan. Biasanya, media regional terbesar di Jawa Barat ini membahas permasalahan lingkungan di sekitar Jawa Barat dalam rubrik "Bandung Raya" dan "Jawa Barat". Isu lingkungan memang menjadi salah satu prioritas utama surat kabar harian yang berdiri sejak 24 Maret 1967 ini, bisa dilihat dari jumlah berita lingkungan yang diterbitkan oleh Pikiran Rakyat. Bahkan, bila dibandingkan dengan Kompas yang memiliki rubrik khusus lingkungan, Pikiran Rakyat lebih banyak memberitakan isu lingkungan.

Isu-isu lingkungan yang diangkat oleh Pikiran Rakyat dikemas dalam bentuk berita langsung dan berita khas, di mana beberapa berita langsungnya juga sering kali menjadi berita utama. Dari hasil pendataan yang dilakukan peneliti, selama bulan September 2015 - Januari 2016 tercatat sebanyak 461 berita lingkungan naik cetak. Berita-berita tersebut tersebar di beberapa rubrik, yakni 209 berita dicetak pada rubrik "Bandung Raya", 208 berita dicetak pada rubrik "Jawa Barat", dan 44 berita dicetak di rubrik lainnya seperti "Dalam Negeri", "Horizon", "Berakhir Pekan" maupun "Ekonomi dan Bisnis". Sedangkan jumlah berita lingkungan yang dijadikan berita utama atau headline sebanyak 136 berita, terdiri dari 87 berita pada rubrik "Bandung Raya", dan 69 berita pada rubrik "Jawa Barat". Rubrik "Bandung Raya" sendiri memiliki tiga halaman, mulai dari halaman 3 sampai halaman 5. Rubrik "Jawa Barat" pun memiliki tiga halaman, mulai dari halaman 13 sampai 15, atau halaman 14 sampai 16. Melalui data berita September 2015 - Januari 2016, peneliti bisa mengetahui siapa saja wartawan yang menjadikan isu lingkungan sebagai arus utama pemberitaan. Dengan begitu, peneliti bisa menentukan subjek penelitian untuk penelitian ini.

Perlu diketahui, Jawa Barat sendiri memiliki banyak permasalahan lingkungan, seperti pengerukan tebing Citatah di Padalarang, penambangan pasir Gunung Tampomas di Sumedang, buruknya sanitasi, pembuangan limbah medis ke Gunung Kamojang Kabupaten Garut, minimnya air bersih, sampah menumpuk, dan alih fungsi lahan. Bila melihat data pencemaran lingkungan tahun 2014, menurut Badan Pusat Statistik, Jawa Barat termasuk dalam tiga besar provinsi dengan tingkat pencemaran air tertinggi oleh industri, yakni sebanyak 58,62\%. Permasalahan itulah yang melatarbelakangi mengapa Pikiran Rakyat sering mengangkat isu-isu lingkungan sebagai berita utama. Menurut redaktur "Bandung Raya" Pikiran Rakyat Satrya Graha, permasalahan lingkungan

http://jurnal.unpad.ac.id/kajian-jurnalisme 
Kajian Jurnalisme

ISSN 2549-0559 (cetak) ISSN 2549-1946 (online)

Volume 01 Nomor 02 Tahun 2018

di Bandung saja sudah sangat banyak meski lingkupnya kecil. Harusnya, permasalahan dengan lingkup kecil seperti itu bisa diatasi, tapi kenyataannya masih belum terselesaikan sampai saat ini. Posisi lingkungan hidup dalam media juga tak jauh berbeda dengan agenda isu lain yang ada di media. Perbedaan mendasar terletak pada peliputan dan produksi beritanya.

Isu lingkungan (yang kemudian dalam bentuk jurnalistiknya disebut sebagai jurnalisme lingkungan) menitikberatkan peliputan dan produksi berita pada realitas lingkungan hidup, seperti kerusakan lingkungan akibat olah tangan manusia (pencemaran, banjir, tanah longsor, penggundulan hutan), kearifan lokal, konservasi, limbah, penggunaaan sumber daya alam (Abrar, 1993: 48). Oleh karena itu, isu lingkungan juga dapat disajikan pada berita utama atau headline, opini, berita ringan, maupun karya jurnalistik lainnya. Namun, dalam penelitian ini, peneliti lebih memfokuskan pada berita lingkungan yang dijadikan sebagai berita utama atau headline. Mengapa? Dengan ciri-ciri berita utama, yakni judul yang menarik, ditulis dengan ukuran yang lebih besar dan tebal membuat berita utama lebih menarik perhatian para pembaca.

Agar berita lingkungan bisa memberikan dampak semua lapisan masyarakat, maka berita lingkungan perlu dibahas secara terus menerus. Pentingnya pembahasan secara berkesinambungan juga disampaikan Erna Witoelar dalam pengantar buku 34 Prinsip Etis Jurnalisme Lingkungan karya Agus Sudibyo. Jurnalisme lingkungan harus memberitakan persoalan-persoalan lingkungan dalam jangka lebih panjang dan lebih sering. Jurnalisme lingkungan bukanlah pemberitaan model sekali muat kemudian selesai. Jurnalisme lingkungan adalah jurnalisme yang memotret persoalan lingkungan sejak hulu hingga hilir. Tugas jurnalisme lingkungan adalah mengangkat fenomenafenomena tersebut agar terlihat, sekaligus memperbanyak pemberitaannya. Oleh karena itu, wartawan lingkungan memerlukan kepekaan, pembelajaran khusus, dan keahlian tertentu dalam memberitakan persoalan-persoalan lingkungan secara profesional (Sudibyo, 2014: xi).

Persoalan lingkungan rata-rata adalah persoalan yang rumit dan membutuhkan kerja keras dan ketekunan untuk memahaminya. Oleh karenanya, wartawan lingkungan bukan hanya perlu mendengarkan apa yang dikatakan manajemen perusahaan, aktivis LSM, pakar lingkungan atau tokoh masyarakat, tetapi juga harus bertemu dan memanggil informasi dari warga kebanyakan di pelosok pedesaan, di pinggir hutan, atau di bantaran sungai di perkotaan (Baskoro, 2003:11-12). Pengetahuan dan daya analisis wartawan diperlukan untuk melihat seperti apa liputan yang dihasilkan dan seperti apa publikasi yang baik sehingga masyarakat dapat menerima dan mengerti.

Berdasarkan pemaparan tersebut, peneliti tertarik untuk meneliti fenomena wartawan rubrik "Bandung Raya" dan "Jawa Barat" Harian Umum Pikiran Rakyat memaknai peliputan isu lingkungan sebagai berita utama. Dalam penelitian ini, peneliti ingin mengetahui motif apa saja yang menjadi latar belakang para wartawan memilih untuk meliput isu lingkungan dan mengarusutamakannya. Selain itu, peneliti juga akan mencari tahu bagaimana pemahaman para wartawan mengenai isu lingkungan, pengalaman mereka meliput isu lingkungan, dan pemaknaan mereka mengenai dampak isu lingkungan yang dijadikan sebagai berita utama. Dengan 
238 | Kajian Jurnalisme

ISSN 2549-0559 (cetak) ISSN 2549-1946 (online)

Volume 01 Nomor 02 Tahun 2018

pemahaman, pengalaman, dan pemaknaan, para wartawan bisa mengkonstruksi realitas mengenai peliputan isu lingkungan sebagai berita utama.

\section{Metode}

Untuk membedah motif para wartawan, peneliti menggunakan Teori Fenomenologi Alfred Schutz, di mana motif terbagi dalam dua fase: in-order-to-motive dan because motive (Kuswarno, 2013: 111). Untuk membahas konstruksi tersebut, peneliti menggunakan Teori Konstruksi Realitas Sosial Peter Berger dan Thomas Luckmann. Pada teori ini, terdapat tiga momen dialektis yang menurut Berger, berlangsung terus menerus dalam mengkontruksi realitas sosial: eksternalisasi, objektivasi, dan internalisasi (Berger, dkk, 2013: xx). Setelah mencapai taraf internalisasi ini, individu menjadi anggota masyarakat: proses ontogenetik untuk mencapai taraf itu adalah sosialisasi, yang dengan demikian dapat didefinisikan sebagai pengimbasan individu secara komprehensif dan konsisten ke dalam dunia objektif suatu masyarakat atau salah satu sektornya. Sosialiasi terbagi menjadi dua, yakni sosialisasi primer dan sosialisasi sekunder (Berger, dkk, 2013: 178).

Data dikumpulkan melalu wawancara mendalam; observasi partisipatif, untuk dapat mengobservasi bagaimana informan bekerja dan melakukan kegiatan sehari-hari. Peneliti bertemu secara langsung dan melakukan pengumpulan data untuk keperluan penelitian. Peneliti juga memperhatikan bagaimana informan akan melakukan peliputan isu lingkungan, dan bagaimana informan berinteraksi dengan narasumber dan sumber beritanya. Observasi ini mendukung peneliti dalam memperoleh data dan memahami informan, selain menggunakan wawancara mendalam. Penelitian juga dilengkapi dengan penelusuran dokumen yang relevan dengan topik penelitian ini.

\section{Hasil Dan Pembahasan}

Masalah lingkungan hidup di Indonesia yang mendapat perhatian media massa cukup beragam dan bahkan akhir-akhir ini beberapa di antaranya mengandung fenomena yang relatif baru. Isu yang kini mulai mendapat perhatian lebih besar dari media seperti, masalah cuaca setelah terjadi kebakaran hutan. Banyaknya permasalahan lingkungan yang terjadi di Indonesia, dirangkum secara garis besar ke dalam 4P: population (kependudukan), pollution (pencemaran), policy (kebijakan), dan poverty (kemiskinan) (Atmakusumah, dkk, 1996: 103).

Untuk permasalahan lingkungan di Provinsi Jawa Barat telah teridentifikasi beberapa pokok permasalahan, seperti persoalan degradasi sumberdaya alam khususnya air dan lahan; permasalahan pencemaran, baik air, udara maupun tanah yang penyebarannya sudah cukup meluas dan terkait dengan industri, rumah tangga dengan segala jenis limbahnya, terutama sampah; bencanaan alam, terutama Jawa Barat bagian tengah dan selatan yang termasuk wilayah rawan gempa dan volkanisme; inkonsistensi antara Rencana Tata Ruang Wilayah dengan eksisting penggunaan lahan/pemanfaatan ruang yang tidak berwawasan lingkungan; permasalahan kawasan pesisir dan pantai, yaitu kerusakan hutan mangrove, abrasi dan akresi pantai, perubahan tataguna http://jurnal.unpad.ac.id/kajian-jurnalisme 
Kajian Jurnalisme

ISSN 2549-0559 (cetak) ISSN 2549-1946 (online)

Volume 01 Nomor 02 Tahun 2018

lahan di wilayah pesisir, intrusi air laut, dan pencemaran air laut; permasalahan sosial kependudukan; serta tumpang-tindih peraturan perundang-undangan dalam bidang lingkungan. Isu-isu lingkungan yang sering diangkat oleh Pikiran Rakyat biasanya dimuat pada rubrik "Bandung Raya", "Jawa Barat", "Dalam Negeri", dan "Ekonomi dan Bisnis". Namun, isu lingkungan paling sering dimuat pada rubrik "Bandung Raya" dan "Jawa Barat". Dari hasil pendataan yang dilakukan peneliti, selama bulan September 2015 - Januari 2016 tercata sebanyak 461 berita lingkungan naik cetak. Berita-berita tersebut membahas beberapa isu lingkungan, seperti kekeringan, pencemaran sungai, dan sampah yang terjadi di sekitar kota dan kabupaten Bandung. Kemudian isu mengenai minimnya air bersih, gagal panen karena kemarau, alih fungsi lahan, dan kebakaran hutan di sekitar Jawa Barat dibahas pada rubrik "Jawa Barat”.

\section{Jurnalisme Lingkungan}

Jurnalisme lingkungan hidup adalah jurnalisme yang berfokus pada hal ihwal yang berkaitan dengan lingkungan hidup. Pewujudannya dapat berupa pemberitaan, uraian, komentar, serta lontaran pendapat para pakar, peminat, dan pengamat tentang lingkungan hidup dengan berbagai masalahnya (Atmakusumah, dkk, 1996: 72). Makna jurnalisme lingkungan juga dipaparkan oleh Erna Witoelar dalam pengantar 34 Prinsip Etis Jurnalisme Lingkungan.

"Jurnalisme lingkungan adalah jurnalisme yang memotret persoalan lingkungan sejak hulu hingga hilir. Jurnalisme ini bukanlah jurnalisme populer yang menulis isu lingkungan ketika ia sedang menjadi perhatian jutaan umat manusia. Jurnalisme lingkungan memberitakan upayaupaya penanganan masalah lingkungan yang mengawal proses penanganan masalah sampai munculnya solusi-solusi yang ditemukan kemudian" (Sudibyo, 2014: x).

Jurnalisme lingkungan berkembang pada tahun 1980-an, ketika insiden lingkungan banyak terjadi di negara-negara barat. Pada saat itu bencana lingkungan dalam skala besar terjadi di berbagai belahan dunia, seperti limbah merkuri di perairan Ontario, hujan asam, rusaknya habitat burung akibat penggunaan pestisida, hingga insiden nuklir di kota Chernobyl, Ukraina yang menyebabkan lebih dari lima juta orang terpapar radiasi zat radioaktif penyebab kanker. Sejak itu, kesadaran akan pentingnya menyajikan liputan yang dapat menggugah kesadaran terhadap bahaya lingkungan mulai muncul di kalangan media massa. Dalam membuat liputan peristiwa-peristiwa di atas, media dibanjiri informasi dari seluruh aspek yang berkaitan dengan persoalan tersebut, mulai dari aspek sosial, hukum, ekonomi, maupun politik. Akan tetapi, aspek lingkungan yang menjadi akar persoalan justru tidak banyak disentuh karena ketidakmampuan jurnalis memahami persoalan lingkungan secara komprehensif.

Keadaan ini mengundang keprihatinan dari para praktisi media, sehingga pada tahun 1990an berdiri The Society of Environmental Journalists (SEJ) yang dipelopori The Philadelphia Inquirer, USA Today, Turner Broadcasting, Minnesota Public Radio, dan National Geographic. Misi dari organisasi ini adalah untuk menguatkan kualitas, capaian, dan viabilitas dari jurnalisme 
dalam memberikan informasi kepada publik untuk memahami isu lingkungan (Rademakers, Tesis, 2004: 4). Terbentuknya SEJ diikuti oleh pendirian organisasi-organisasi professional yang juga concern terhadap persoalan lingkungan, juga lembaga-lembaga kajian maupun institusi akademis, seperti The Environmental Journalism Center of The Radio - TV News Director Association and Foundation (1991), Center for Environmental Journalism - University of Colorado (1992), International Federation of Environmental Journalists (1993), Knight Center for Environmental Journalism - Michigan State University (1994), Earth Journalism Network (2004).

Mengingat pengertian holistik lingkungan hidup, baik lingkungan fisik maupun lingkungan sosial budayanya, pendekatan jurnalisme lingkungan hidup adalah pendekatan holistik pula -- yang bersifat menyeluruh. Mereka yang berkecimpung di dalam jurnalisme lingkungan hidup, mulai dari wartawan pencari dan peliput berita di lapangan sampai ke redaktur utama, diharapkan akan senantiasa mengikuti perkembangan bidang lingkungan hidup (Atmakusumah, dkk, 1996: 73).

Ruang lingkup jurnalisme lingkungan juga tergolong kompleks sebab persoalan lingkungan hidup juga hampir tidak pernah berdiri sendiri, selalu bersilang-sengkarut dengan masalah sosial, politik, ekonomi, budaya, dan ilmu pengetahuan (Sudibyo, 2014: 9).

Lalu apa fungsi dan tujuan jurnalisme lingkungan? Jurnalisme lingkungan dapat dilihat sebagai usaha menyampaikan seruan kepada semua pihak untuk berpartisipasi dalam gerakan menyelamatkan kelestarian lingkungan hidup. Pers pada dasarnya adalah agen masyarakat untuk mengontrol kekuasaan dan memperjuangkan kepentingan-kepentingan publik. Penyelamatan lingkungan hidup adalah bagian dari kepentingan publik. Maka, jurnalisme lingkungan adalah bagian dari bentuk tanggung jawab pers untuk memperjuangkan kepentingan publik. Pers harus memiliki sikap yang jelas terhadap persoalan lingkungan hidup yang hampir selalu berbenturan dengan kepentingan ekonomi dan kepentingan politik (Sudibyo, 2014: 5).

\section{Pemahaman Mengenai Isu Lingkungan Sebelum Menjadi Wartawan}

Sosialisasi primer adalah sosialiasi yang pertama yang dialami individu dalam masa kanakkanak, yang dengan itu ia menjadi anggota masyarakat. Sosialisasi sekunder adalah setiap proses berikutnya yang mengimbas individu yang sudah disosialisasikan itu ke dalam sektor-sektor baru dunia objektif masyarakat (Berger, dkk, 2013: 178). Dalam sosialisasi primerlah, dunia pertama individu terbentuk. Sifat sosialisasi primer dipengaruhi oleh berbagai persyaratan dalam pengalihan cadangan pengetahuan. Dalam relevansinya dengan hasil wawancara bersama para informan, sosialisasi primer mengenai isu lingkungan diperoleh para informan sejak kecil dan semasa di bangku kuliah. Mereka memperoleh pengetahuan mengenai isu lingkungan sebelum menjadi wartawan dari pengalaman mereka secara langsung maupun dari media, seperti koran dan televisi.

Dari hasil meliput beberapa peristiwa dan isu, para informan menemukan isu-isu yang membuat mereka tertarik untuk membahasnya lebih rutin. Salah satu isu tersebut adalah isu lingkungan. Di sinilah muncul beragam motif para informan tertarik memilih untuk meliput isu 
Kajian Jurnalisme

ISSN 2549-0559 (cetak) ISSN 2549-1946 (online)

Volume 01 Nomor 02 Tahun 2018

lingkungan. Isu-isu tersebut dikemas dalam beragam jenis berita, yakni berita langsung, berita khas, dan berita mendalam. Pengemasan berita dari hasil pengalaman dan pengetahuan yang telah diperoleh para informan saat meliput, merupakan tahap objektivasi. Berita lingkungan yang ditulis para informan kerap diangkat menjadi berita utama oleh redaktur rubrik "Bandung Raya" dan rubrik "Jawa Barat".

Media massa diakui oleh Walhi Indonesia sebagai alat yang paling efektif untuk melibatkan publik dalam perdebatan mengenai pembangunan berkelanjutan. Tapi, untuk merangsang perdebatan, Walhi mengatakan liputan media massa tidaklah cukup apabila hanya sekadar berupa berita, melainkan perlu berbentuk kisah dan berita mendalam (Atmakusumah, dkk, 1996: x). Memberikan informasi melalui media massa tentu lebih efektif karena salah satu kelebihan komunikasi massa dibandingkan dengan komunikasi lainnya adalah jumlah sasaran khalayak atau komunikan yang dicapainya relatif banyak dan tidak terbatas. Bahkan lebih dari itu, komunikan yang banyak tersebut secara serempak pada waktu yang bersamaan memperoleh pesan yang sama pula (Ardianto dkk, 2007:9).

Bila melihat dari empat fungsi media massa (informasi, edukasi, hiburan, dan persuasif), fungsi yang paling menonjol pada surat kabar adalah informasi. Hal ini sesuai dengan tujuan utama khalayak membaca surat kabar, yaitu keingintahuan akan setiap peristiwa yang terjadi di sekitarnya. Untuk memperoleh informasi yang berkala secara intensif, surat kabar memiliki karakteristik yang lebih utama dibandingkan dengan media eletronik seperti radio dan televisi. Karakteristik tersebut adalah periodesitas dan terdokumentasikan.

Untuk menyerap isi surat kabar, pembaca dituntut untuk bisa membaca serta memiliki kemampuan intelektualitas tertentu. Khalayaknya yang buta huruf tidak dapat menerima pesan surat kabar. Berbeda dengan khalayak radio dan televisi, yang buta huruf dan yang berpendidikan rendah dapat menerima informasi meski tidak semuanya (Ardianto dkk, 2007:117-118). Dengan kelebihan tersebut, isu-isu penting yang membutuhkan waktu berkala dalam penyampaiannya, seperti isu lingkungan sangat cocok dipublikasikan melalui surat kabar. Isu lingkungan dianggap menarik untuk dikaji karena permasalahannya yang kompleks, sehingga perlu disampaikan secara terus menerus. Namun, sayangnya masih jarang media massa yang secara rutin mengangkat isu lingkungan.

Alasan tersebut menjadi alasan mengapa Pikiran Rakyat sering mengangkat isu lingkungan dalam pemberitaan yang mereka buat. Dengan mengarusutamakan isu lingkungan, diharapkan bisa memberikan dampak bagi masyarakat dan mengubah kondisi lingkungan lebih baik. Kerap dijadikan berita utama membuat para informan memiliki pemaknaan tersendiri mengenai dampak dari isu lingkungan bila menjadi berita utama. Pemaknaan tersebut termasuk dalam proses internalisasi, di mana proses tersebut dihasilkan dari proses ekternalisasi dan objektivasi. Dengan pemaknaan tersebut, pemahaman atau pengetahuan dan sudut pandang para informan mengenai isu lingkungan pun semakin bertambah setelah menjadi wartawan.

http://jurnal.unpad.ac.id/kajian-jurnalisme 
242 | Kajian Jurnalisme

ISSN 2549-0559 (cetak) ISSN 2549-1946 (online)

Volume 01 Nomor 02 Tahun 2018

Kondisi tersebut termasuk dalam sosialisasi sekunder, yakni proses memperoleh pengetahuan khusus sesuai dengan peranannya, di mana peranan-peranan secara langsung atau tidak langsung berakar dalam pembagian kerja (Berger, dkk, 2013: 189-191). Sosialisasi sekunder para informan adalah pemahaman mereka mengenai isu lingkungan setelah menjadi wartawan.

Dari hasil wawancara, peneliti membagi dua kategori dalam sosialisasi primer para informan memahami isu lingkungan sebelum mejadi wartawan: 1) Cara memperoleh informasi, dan 2) Pandangan mengenai isu lingkungan. Cara para informan memperoleh informasi mengenai isu lingkungan terdiri dari tiga pola: 1) Dari hasil menonton media elektronik (TV) dan membaca media cetak (koran); 2) Pengalaman semasa kecil saat melihat kondisi lingkungan; dan 3) Pengalaman menjadi pecinta alam.

Seorang informan menuturkan pendapatnya mengenai isu lingkungan sebelum menjadi seorang wartawan. Pengalamannya menjadi anggota pecinta alam membuatnya lebih peka terhadap isu lingkungan. Sehingga dari sanalah informan tersebut bisa memperoleh pemahaman mengenai kondisi lingkungan saat itu. Karena minatnya pada lingkungan, informan tersebut memutuskan untuk bergabung dalam komunitas Zero Waste.

Sedangkan pemahaman mengenai isu lingkungan menurut para informan terdiri dari empat kategori: 1) Terjadi kesalahan dalam pengelolaan lingkungan; 2) Kondisi lingkungan sulit diubah; 3) Perubahan cuaca yang memburuk; dan 4) Semua aktivitas akan menimbulkan dampak.

Sosialisasi primer menciptakan di dalam kesadaran seseorang mengenai suatu abstraksi yang semakin tinggi dari peranan-peranan dan sikap orang-orang lain tertentu ke peranan-peranan dan sikap pada umumnya (Berger, dkk, 2013: 181). Dalam konteks penelitian ini, para informan mengeneralisasikan kondisi lingkungan sesuai dengan pengetahuan yang mereka peroleh dari pengalaman langsung, dan media massa. Para informan menganggap kondisi lingkungan yang mereka lihat di tempat tinggalnya terjadi juga di tempat lain. Para informan menginternalisasi kondisi lingkungan yang mereka ketahui sebagai salah satu kasus dari sekian banyak permasalahan lingkungan. Namun, mereka menginternalisasinya sebagai satu-satunya kondisi yang sedang terjadi dan yang bisa dipahami. Berger mengatakan, maka dalam sosialisasi primerlah dunia pertama individu terbentuk (Berger, dkk, 2013: 185).

Sosialisasi primer berakhir bila konsep tentang orang lain pada umumnya (dan segala sesuatu yang menyertainya) telah terbentuk dan tertanam dalam kesadaran individu (Berger, dkk, 2013: 188). Di mana, para informan sudah menjadi anggota efektif masyarakat dan secar subjektif memiliki suatu diri dan sebuah dunia yakni sebagai wartawan dalam dunia jurnalistik. Namun, sejatinya menurut Berger dkk, sosialisasi tidak pernah total dan tak pernah selesai (Berger, dkk, 2013: 188).

\section{Motif Mengarusutamakan Isu Lingkungan}

Selain makna “intersubjektif”, dunia sosial menurut Schutz, harus dilihat secara historis. Oleh karenanya, Schutz menyimpulkan bahwa tindakan sosial adalah tindakan yang berorientasi 
Kajian Jurnalisme

ISSN 2549-0559 (cetak) ISSN 2549-1946 (online)

Volume 01 Nomor 02 Tahun 2018

pada perilaku orang atau orang lain pada masa lalu, sekarang, dan akan datang. Untuk menggambarkan keseluruhan tindakan seseorang, perlu diberi fase. Dua fase yang diusulkan Schutz diberi nama tindakan in-order-motive, yang merujuk pada masa yang akan datang, dan tindakan because-motive yang merujuk pada masa lalu.

Pada penelitian ini, because-motive (masa lalu) para informan dalam meliput isu lingkungan adalah 1) Isu lingkungan banyak ditemukan, 2) Isu yang kompleks, 3) Latar belakang sebagai pecinta alam, dan 4) Isu lingkungan jarang diangkat media lain.

Informan lain memaparkan motifnya meliput isu lingkungan karena jarangnya isu lingkungan diangkat oleh media lain. Informan tersebut menilai, isu politik jauh lebih diperhatikan masyarakat, maka dari itu bisa dikatakan hampir semua media massa memiliki rubrik politik. Dari sinilah informan tersebut melihat peluang untuk membahas isu yang berbeda dan jarang diangkat oleh media lain. Menurutnya, isu lingkungan kan jarang ada yang angkat. Masalah lingkungan di kota itu memang banyak, seperti sampah, air tanah, plastik berbayar, tapi hal-hal yang seperti itu jarang terliput.

Dengan melihat pengalaman dan pengetahuan sebelumnya tentang meliput isu lingkungan, para informan pun menuju pada fase tindakan berikutnya yakni in-order-motive (masa depan). Pada fase ini, peneliti membagi motif para informan meliput isu lingkungan menjadi dua motif: 1) Ingin memberikan dampak, dan 2) Isu lingkungan perlu mendapat perhatian.

Pada fase motif, selain mengetahui tujuan para informan dalam mengarusutamakan isu lingkungan, kemauan dan kemampuan mereka dalam mengarusutamakan isu lingkungan pun bisa terlihat. Para informan mau untuk mengarusutamakan isu lingkungan. Namun, masih ada beberapa yang belum mampu untuk mengarusutamakan isu lingkungan, seperti temuan atas salah seorang informan. Informan tersebut merasa karena kesulitan yang ia peroleh, baik itu di lapangan atau dari pihak kantor sendiri, serta sulitnya membuat dampak dari pemberitaan membuat ia merasa belum mampu mengarusutamakan isu lingkungan.

\section{Pengalaman Selama Meliput Isu Lingkungan}

Eksternalisasi merupakan penyesuaian diri dengan dunia sosiokultural sebagai produk manusia. Dalam bukunya, Berger dan Luckmann menjelaskan, kenyataan hidup sehari-hari yang dialami oleh individu merupakan gambaran dari hal-hal nyata yang berada dalam kesadaran individu tersebut. Kenyataan kehidupan sehari-hari tidak hanya sebatas "di sini dan sekarang”, tapi lebih jauh dari itu, baik dari segi ruang maupun waktu. Maka, kenyataan hidup sehari-hari itu selanjutnya menghadirkan diri seorang individu sebagai suatu intersubjektif, suatu dunia yang ia huni bersama dengan orang-orang lain. Sebagai seorang individu, para informan perlu menyesuaikan diri dengan profesi mereka sebagai wartawan dalam sosiokultural dunia jurnalistik, yakni narasumber, wartawan lain, dan lokasi peliputan.

http://jurnal.unpad.ac.id/kajian-jurnalisme 
244 | Kajian Jurnalisme

ISSN 2549-0559 (cetak) ISSN 2549-1946 (online)

Volume 01 Nomor 02 Tahun 2018

Pada poin ini, peneliti membahas penyesuaian diri informan dengan narasumber dan wartawan lain. Dari hasil wawancara mendalam dan observasi partisipatif, terdapat empat cara penyesuaian diri para informan, yakni 1) Memperluas link dengan pejabat daerah, 2) Berdiskusi dengan wartawan lain, 3) Ramah, dan 4) Menggunakan bahasa daerah. Semua informan menyesuaikan diri dengan cara ini. Salah seorang nara sumber menuturkan, meski ia telah lama berada dalam dunia jurnalistik sebagai seorang penyunting berita, tapi ia perlu menyesuaikan dirinya dengan sosio-kultural dunia jurnalistik kala memilih menjadi wartawan. Nara sumber tersebut mengaku menyesuaikan diri dengan cara menjalin relasi dari berbagai kalangan, mulai dari 'jagoan' setempat hingga dinas-dinas terkait agar lebih mudah untuk memperoleh informasi. Ia juga masuk dalam organisasi kewartawanan, Persatuan Wartawan Indonesia (PWI), sehingga mempermudah dirinya dalam menyesuaikan diri saat meliput ke lapangan.

Dari hasil wawancara mendalam dan observasi partisipatif, terdapat empat cara penyesuaian diri para informan dengan narasumber dan wartawan lain, yakni 1) Memperluas link dengan pejabat daerah, 2) Berdiskusi dengan wartawan lain, 3) Ramah, dan 4) Menggunakan bahasa daerah. Sedangkan, untuk penyesuaian diri wartawan dengan lokasi peliputan, para informan menemukan beberapa kesulitan, di antaranya: 1) Preman, 2) Pelaku pencemaran tidak mau konfirmasi, 3) Memerlukan banyak waktu, dan 4) Masyarakat pro eksploitasi.

Kesulitan dalam peliputan ternyata tak hanya datang dari narasumber atau sumber berita, tapi juga dari pihak eksternal, seperti preman. Kesulitan dalam menghadap preman saat meliput dirasakan oleh tiga orang informan. Salah seorang informan mengaku, selain para 'backing-an', hal yang paling sulit dalam meliput isu lingkungan adalah dampak pemberitaan itu sendiri.

"Saya juga kalau ditugaskan di daerah mana gitu, pasti saya cari link, harus tahu siapa kepala-kepala dinas, siapa 'jagoan' di daerah sini, siapa yang sering jadi 'backing-an'. Biar kalau ada apa-apa, saya juga bisa minta tolong lah buat bantu. Soalnya susah tuh urusannya kalau udah ada backing-an. Susah tuh urusannya kalau udah ada backing-an. Terus, ya yang susah itu membuat dampak dari pemberitaan sih", tutur sang informan.

Informan lain juga pernah mengalami kesulitan karena tindakan dari preman saat ia bertugas meliput isu pencemaran limbah cair di Sungai Cihudang oleh salah satu pabrik kertas. Pihak pengelola pabrik tersebut ternyata memiliki backing-an preman yang menghambat peliputan informan tersebut.

"Pernah ada pencemaran limbah cair di Sungai Cihudang, Kecamatan Bojongsoang, Ciwastra. Itu dulu beritanya Akang buat akhir tahun 2015. Di sana ada satu pabrik kertas di sana. Dia mikirnya karena punya backing-an, jadi merasa terbantu lah. Ya sudah, sama Akang diberitain aja", ungkap sang informan.

Kesulitan-kesulitan tersebut diatasi oleh para informan dengan berbagai penyesuaian. Peneliti membaginya menjadi empat cara penyesuaian diri, yakni 1) Menjalin relasi, 2) Membuat judul dan konten provokatif, 3) Pemberitaan terus menerus, dan 4) Mengangkat sisi lain dari peristiwa isu lingkungan.

http://jurnal.unpad.ac.id/kajian-jurnalisme 
Kajian Jurnalisme

ISSN 2549-0559 (cetak) ISSN 2549-1946 (online)

Volume 01 Nomor 02 Tahun 2018

Pada tahap objektivasi, di mana para informan mengsignifikasi pengetahuan dan pengalaman mereka dalam bentuk berita. Berita-berita tersebut ditulis dalam beragam jenis: berita langsung, berita khas, dan berita mendalam. Namun, kebanyakan lebih sering menulis dalam bentuk berita langsung karena dirasa lebih mudah, dan cepat untuk dibuat. Berita-berita tesebut memuat isu-isu lingkungan yang kerap diliput oleh para informan, seperti alih fungsi lahan, sampah, pembangunan, pencemaran limbah, dan longsor. Berita langsung yang ditulis oleh para informan pun kerap dijadikan berita utama oleh para redaktur "Bandung Raya" dan "Jawa Barat".

Untuk menyesuaikan diri dengan lokasi peliputan, seluruh informan mengatakan harus meliput langsung turun ke lapangan. Menurut salah seorang informan, kegunaan dari meliput langsung ke lokasi adalah membuat dirinya jadi lebih mengetahui kondisi yang sebenarnya. Namun, tentu banyak kendala yang dialami bila wartawan terjun langsung meliput ke lapangan, seperti yang dipaparkan seorang informan lain. Menurutnya, bila terjun langsung ke lapangan, konsekuensinya wartawan harus mau merasakan keadaan yang sebenarnya. Seperti saat ia meliput banjir dan tumpukan sampah ilegal di Baleendah, merasakan bagaimana sulitnya melalui jalanan banjir dan bau-bauan sampah yang sudah berbulan-bulan menumpuk.

Selain konsekuensi tersebut, masih ada lagi beberapa kesulitan yang harus dihadapi para informan bila meliput langsung ke lapangan, yakni 1) Preman, 2) Keterangan pengelola pabrik, 3) Memerlukan banyak waktu, dan 4) Masyarakat pro eksploitasi. Kesulitan-kesulitan tersebut diatasi oleh para informan dengan berbagai penyesuaian, di antaranya: 1) Menjalin relasi, 2) Judul dan konten provokatif, 3) Pemberitaan terus menerus, dan 4) Angkat angle lain. Sebelum ditugaskan ke Garut, seorang pernah mengalami kendala liputan karena preman setempat. Maka dari itu, informan tersebut mengatakan selain menjalin relasi dengan para pejabat dinas, seorang wartawan juga perlu menjalin relasi dengan para preman setempat.

Kesulitan selanjutnya yang dialami oleh para informan adalah kesulitan dalam melakukan verifikasi terhadap pengelola pabrik yang membuat limbah secara ilegal ke sungai, seperti yang dialami dua orang informan. Cara penyesuaian diri mereka untuk menghadapi kesulitan ini adalah dengan memberitakan isu tersebut dengan judul dan isi yang provokatif untuk menyentil pengelola pabrik.

Meliput isu lingkungan, apalagi dalam teknik investigasi mendalam tentu memerlukan waktu yang relatif lama. Maka dari itu, penyesuaian diri yang dilakukan oleh salah seorang informan dalam menghadapi kesulitan tersebut dengan cara memberitakan isu lingkungan secara terus menerus. Meliput isu lingkungan yang mendalam itu memerlukan banyak waktu. Berita lingkungan itu harus dibuat terus menerus, soalnya bayak media kurang menyorot isu lingkungan, dan pembaca juga sepertinya tidak terlalu tertarik dengan isu lingkungan, entah mengapa.

Kemudian, kesulitan selanjutnya yakni di mana masyarakat yang biasanya menolak kerusakan lingkungan, tapi justru masyarakat tersebut mendukung bahkan ketergantungan dengan

http://jurnal.unpad.ac.id/kajian-jurnalisme 
Kajian Jurnalisme

ISSN 2549-0559 (cetak) ISSN 2549-1946 (online)

Volume 01 Nomor 02 Tahun 2018

pengeksploitasian lingkungan. Dalam menghadapi kesulitan ini, salah seorang informan mengaku biasanya akan mengambil angle berita lain agar pola pikir masyarakat bisa dibenahi.

Suatu tipifikasi akan berlangsung sampai ada perkembangan lain, yang menentukan tindakan-tindakan seseorang. Tipifikasi yang terjadi dalam interaksi sosial memiliki keterbukaan yang sama karena campur tangan dari kedua belah pihak. Skema tipifikasi itu "bernegosiasi" terus menerus dalam situasi tatap muka. Kemudian, tipifikasi yang ada dan baru terbentuk terjadi secara kesinambungan (Berger,dkk, 2013: 43). Meski terdapat perbedaan perspektif dengan orang lain mengenai dunia, hal yang paling penting adalah penyesuaian yang berlangsung terus menerus antara makna-makna individu tersebut dengan makna-makna orang lain di dunia ini (Berger, dkk, 2013: 31-33). Dalam konteks penelitian ini, para informan melakukan tipifikasi mengenai makna kondisi lingkungan yang mereka liput melalui penyesuaian diri dengan para narasumber, wartawan lain, dan lokasi peliputannya. Kemudian, para informan menentukan tindakan apa yang harus ia lakukan setelah melakukan tipifikasi isu lingkungan. Sebagai seorang wartawan, tindakan yang dilakukan para informan adalah mengobjektivasikannya dalam tulisan berita lingkungan dengan beragam jenis berita: berita langsung, berita khas, dan berita mendalam.

\section{Objektivasi Melalui Berita Lingkungan}

Tahap selanjutnya dari eksternalisasi adalah objektivasi. Objektivasi merupakan interaksi sosial yang terjadi dalam dunia intersubjektif yang dilembagakan atau mengalami proses institusionalisasi. Objektivasi ini merupakan isyarat-isyarat yang sedikit banyaknya tahan lama dari proses-proses subjektif para produsennya, sehingga memungkinkan objektivasi itu dipakai sampai melampaui situasi tatap muka di mana mereka dapat dipahami secara langsung (Berger, dkk, 2013: 47). Satu kasus yang sangat penting dari objektivasi adalah signifikasi, yakni pembuatan tanda-tanda oleh manusia, bahasa termasuk salah satunya.

Bahasa merupakan sistem tanda yang paling penting dalam masyarakat. Bahasa mampu menjadi tempat penyimpanan yang objektif dari akumulasi makna dan pengalaman yang besar sekali dan yang kemudian dapat dilestarikan dalam waktu dan diteruskan kepada generasi-generasi berikutnya (Berger, dkk, 2013: 50-51). Untuk mengakumulasikan pengetahuan yang berkaitan dengan peranan tertentu, suatu masyarakat harus diorganisasi begitu rupa sehingga individuindividu tertentu dapat memusatkan perhatian kepada keahlian khusus mereka (Berger, dkk, 2013: 105). Peranan-peranan itu tampak sebagai representasi dan perantara kelembagaan dari kumpulankumpulan pengetahuan yang sudah diobjektivasi secara kelembagaan (Berger, dkk, 2013: 106).

Sebagai wartawan, para informan memperoleh pengetahuan mengenai isu lingkungan dari berbagai sumber, seperti pengamatan langsung, wawancara narasumber, dan berita dari media massa. Isu-isu lingkungan yang kerap diliput oleh para informan antara lain: 1) Alih fungsi lahan, 2) Sampah, 3) Pembangunan, 4) Pencemaran limbah, dan 5) Longsor. Intensitas para informan dalam meliput isu lingkungan sangat beragam. Ada yang hampir setiap hari meliput isu lingkungan. Ada yang tiga kali seminggu meliput isu lingkungan, atau minimal sekali dalam

http://jurnal.unpad.ac.id/kajian-jurnalisme 
Kajian Jurnalisme

ISSN 2549-0559 (cetak) ISSN 2549-1946 (online)

Volume 01 Nomor 02 Tahun 2018

seminggu meliput isu lingkungan, namun, ada juga yang tidak tentu dalam seminggu ada liputan isu lingkungan. Salah seorang nara sumber memaparkan alasan bila ia tidak tentu meliput isu lingkungan karena isu yang ia minati bukan hanya isu lingkungan, tapi nara sumber tersebut juga tertarik dengan isu lain seperti kemanusiaan, kriminalitas, dan kesenian.

Setelah melakukan liputan, para wartawan mengakumulasi pengetahuan mereka melalui berita. Beragam jenis berita ditulis oleh para informan. Namun, menurut hasil wawancara yang peneliti lakukan, para informan lebih sering menulis isu lingkungan dalam bentuk berita langsung dan berita khas. Alasannya karena berita langsung lebih mudah dan cepat dibuat. Selain itu, menurut salah seorang lingkungan, dengan menulis berita langsung, isu lingkungan yang ia peroleh bisa dipecah menjadi beberapa tulisan.

Dalam menjelaskan tatanan kelembagaan, terjadi proses legitimasi. Legitimasi mempun yai unsur kognitif maupun normatif. Legitimasi tidak sekadar "nilai-nilai", ia selalu mengimplikasikan "pengetahuan" juga. Legitimasi tidak hanya memberitahukan kepada individu mengapa ia harus melakukan satu tindakan tertentu dan bukan tindakan lainnya, ia juga memberitahukan kepadanya mengapa segala-sesuatu berlangsung seperti apa adanya (Berger, dkk, 2013: 127-128). Beritaberita lingkungan yang ditulis oleh para informan dipilih oleh redaktur rubrik "Bandung Raya" dan "Jawa Barat" untuk dijadikan sebagai berita utama. Dijadikannya isu lingkungan sebagai berita utama oleh Pikiran Rakyat, tentu karena isu lingkungan memiliki nilai berita yang besar.

Mengacu pada nilai berita yang dikemukakan oleh Walter Lippmann dalam dalam bukunya Public Opinion pada tahun 1922 (Kusumaningrat dkk, 2012: 58-66), beberapa nilai berita yang dimiliki isu lingkungan antara lain, aktualitas, kedekatan, dampak, human interest, ketegangan, ketidaklaziman, konflik, simpati, dan binatang. Redaktur "Bandung Raya", Satrya Graha menjelaskan, dengan dijadikannya isu lingkungan sebagai berita utama diharapkan bisa memberikan dampak bagi pemerintah untuk menjalankan regulasi, dan bagi masyarakat agar mau peduli dan peka dengan lingkungan.

\section{Pemaknaan Mengenai Isu Lingkungan sebagai Berita Utama}

Pemaknaan mengenai isu lingkungan sebagai berita utama termasuk dalam tahap internalisasi para informan. Dengan seluruh pengalaman yang telah diperoleh para informan selama meliput isu lingkungan (baik terjun langsung ke lapangan melihat kondisi yang sebenarnya, maupun melalui wawancara atau komunikasi dengan pakar dan pihak terkait), terlebih lagi isu lingkungan yang mereka angkat dijadikan berita utama oleh redaktur masing-masing, para informan pun memperoleh pemaknaan mengenai isu lingkungan sebagai berita utama.

Dari hasil wawancara, pemaknaan yang diberikan oleh para informan mengenai isu lingkungan sebagai berita utama antara lain: 1) Isu lingkungan memiliki nilai penting, 2) Berita harus dipertanggungjawabkan, 3) Isu lingkungan bisa menjadi perhatian utama, 4) Isu lingkungan memiliki nilai proximity tinggi, dan 5) Isu lingkungan memiliki dampak. 
248 | Kajian Jurnalisme

ISSN 2549-0559 (cetak) ISSN 2549-1946 (online)

Volume 01 Nomor 02 Tahun 2018

Salah seorang informan mengaku dirinya bukan tipikal wartawan yang sangat mengejar posisi berita utama. Menurutnya, dipilih menjadi berita utama atau tidak, seorang wartawan harus bisa mempertanggungjawabkan apa yang ia tulis. Meskipun berita yang dibuat oleh wartawan tidak menjadi berita utama, tapi ternyata isinya 'keras', berita tersebut pasti memiliki pengaruh bagi pembaca, terutama pihak terkait. Menurut sang informan, sama aja ya apakah berita tersebut menjadi headline atau bukan, yang penting bisa dipertanggungjawabkan. Kalau ternyata berita tersebut keras meskipun tidak menjadi headline, maka tetap akan dapat berpengaruh. Menurut seorang informan, berita lingkungan memang biasanya dijadikan headline di desk Bandung Raya. Karena menurutnya, redaktur pada desknya lebih senang dengan berita-berita lingkungan. Seorang redaktur memiliki kewenangan untuk memilih berita mana yang naik cetak.

Kemudian, para informan juga memaparkan pandangan mereka mengenai dampak yang dihasilkan oleh berita utama. Dari lima informan, dua di antaranya berpendapat bila berita utama memberikan dampak yang signifikan pada perubahan kondisi lingkungan. Meski begitu, empat informan merasa bila sebaiknya isu lingkungan dikemas dalam rubrik suplemen agar pembahasannya bisa lebih mendalam. Para informan juga memaparkan bagaimana caranya agar berita bisa memberikan dampak bagi pembaca. Beberapa caranya antara lain, 1) Membuat gambaran umum peristiwa, 2) Diberitakan secara terus menerus, dan 3) Memasukkan unsur edukasi.

\section{Pemahaman Mengenai Isu Lingkungan Setelah Menjadi Wartawan}

Setelah menjadi wartawan, para informan memperoleh informasi melalui liputan, info dari link (dinas, wartawan lain), dan mengembangkan berita. Dengan begitu, terbentuklah beberapa pemahaman para informan tentang isu lingkungan setelah menjadi wartawan, antara lain: 1) Pengetahuan mengenai isu lingkungan semakin berkembang, 2) Perlu perhatian semua pihak untuk membenahi lingkungan.

Setelah menjadi wartawan, seorang informan memaknai isu lingkungan sebagai kondisi yang harus ia benahi. Ia merasa prihatin dengan kondisi lingkungan saat ini. Sehingga, informaan tersebut merasa, dengan profesinya sebagai wartawan, salah satu cara untuk membenahi lingkungan adalah tak hanya dengan memberitakannya tapi juga memberikan edukasi dalam beritanya.

"Setelah jadi wartawan karena keprihatinan itu akang merasa harus ada yang dibenahi nih, harus ada yang dilakukan oleh akang. Akang merasa jadi punya kebebasan tersendiri untuk memberitakan permasalahan lingkungan ini. Selain memberitakan kondisi lingkungan, akang juga berusaha untuk memasukkan ilmu-ilmu di dalam tulisan akang biar pembaca itu bisa teredukasi juga", tutur seorang informan.

\section{Simpulan}

http://jurnal.unpad.ac.id/kajian-jurnalisme 
Kajian Jurnalisme

ISSN 2549-0559 (cetak) ISSN 2549-1946 (online)

Volume 01 Nomor 02 Tahun 2018

Berdasarkan hasil penelitian, sebelum menjadi wartawan, para informan memperoleh informasi tentang isu lingkungan dari media massa dan pengalaman secara langsung. Dari sanalah para informan memiliki beberapa pemahaman dasar tentang isu lingkungan. Setelah para informan berprofesi sebagai wartawan, mereka pun melakukan penyesuaian diri terhadap sosio-kultural dunia jurnalistik, yakni terhadap narasumber, wartawan lain, dan lokasi peliputan. Setelah melakukan penyesuaian diri, para informan pun mencari isu apa yang bisa diliput. Isu lingkungan menjadi salah satu isu yang sering mereka liput. Dari pengalaman itulah para informan memiliki beragam motif untuk mengarusutamakan isu lingkungan. Pada fase ini bisa dilihat bagaiaman kemauan dan kemampuan para informan dalam mengarusutamakan isu lingkungan.

Setelah melakukan penyesuaian diri dan memperoleh motif, para informan membuat berita isu lingkungan ke dalam berita langsung yang dijadikan berita utama oleh redaktur. Berdasarkan hal itu, para informan memiliki pemaknaan mengenai isu lingkungan sebagai berita utama antara lain: isu lingkungan memiliki nilai penting, harus dipertanggungjawabkan, isu lingkungan menjadi perhatian utama, nilai proximity tinggi, dan memiliki dampak. Dari lima informan, tiga orang mengatakan, isu lingkungan dijadikan berita utama belum bisa menghasilkan dampak yang signifikan pada lingkungan. Setelah menjadi wartawan, pemahaman informan mengenai isu lingkungan antara lain pengetahuan berkembang dan perlu perhatian semua pihak untuk membenahi lingkungan.

Peneliti menyarankan wartawan rubrik "Bandung Raya” dan "Jawa Barat" perlu keluar dari zona nyaman mereka. Mereka perlu mencoba menulis berita lingkungan dalam bentuk berita mendalam agar bisa membahas banyak aspek. Sebaiknya PR mengangkat isu lingkungan selama dua minggu sekali dalam rubrik "Selisik" agar bisa memberikan dampak yang lebih besar lagi.

\section{Daftar Pustaka}

Abrar, Ana Nadya. (1993). Mengenal Jurnalisme Lingkungan. Semarang: Gadjah Mada University Press. Ardianto, E., Erdinaya, L.K, et.all. (2007). Komunikasi Massa Suatu Pengantar. Bandung: Remaja Rosdakarya.

Atmakusumah, M.I., \& Basorie, W.J. (1996). Mengangkat Masalah Lingkungan ke Media Massa. Jakarta: Yayasan Obor Indonesia.

Baskoro, L.R. (2003). Jurnalisme Lingkungan, Jurnalisme Menggerakkan. Jakarta: Yayasan Karya Jurnalis Indonesia.

Berger, P.L. \& Luckmann, T. (2013). Tafsir Sosial atas Kenyataan. Jakarta: Penerbitan LP3ES.

Bungin, B. (2008). Sosiologi Komunikasi. Jakarta: Kencana.

Bungin, B. (2011). Penelitian Kualitatif. Jakarta: Kencana.

Dewi, P.A.R., (2011). Praktik Jurnalisme Lingkungan oleh Harian Jawa Pos. Jurnal Ilmu Sosial dan Ilmu Politik Volume 15, Nomor 2 (189-206) ISSN 1410-4946.

Djuroto, T. (2004). Manajemen Penerbitan Pers. Bandung: Remaja Rosdakarya.

http://jurnal.unpad.ac.id/kajian-jurnalisme 
250 | Kajian Jurnalisme ISSN 2549-0559 (cetak) ISSN 2549-1946 (online)

Volume 01 Nomor 02 Tahun 2018

Kusumaningrat, H. \& Kusumaningrat, P. (2012). Jurnalistik Teori dan Praktik. Bandung: Remaja Rosdakarya.

Kuswarno, Engkus. (2013). Metodologi Penelitian Komunikasi Fenomenologi Konsepsi, Pedoman, dan Contoh Penelitian. Bandung: Widya Padjadjaran.

Mulyana, Deddy. (2013). Metodologi Penelitian Kualitatif Paradigma Baru Ilmu Komunikasi dan Ilmu Sosial Lainnya. Bandung: Remaja Rosdakarya.

Rakhmat, Jalaluddin. (2002). Metode Penelitian Komunikasi. Bandung: Remaja Rosdakarya.

Romli, Syamsul. (2001). Jurnalistik Terapan Pedoman Kewartawanan dan Kepenulisan. Bandung: Batic Press.

Romli, Syamsul. (2001). Jurnalistik Praktis untuk Pemula. Bandung: Remaja Rosdakarya.

Schutz, Alfred. (1967). The Phenomenology of The Social World. Amerika: Northwestern University Press. Sobur, Alex. (2001). Etika Pers, Profesionalisme dengan Nurani. Bandung: Humaniora Utama Press.

Sudibyo, Agus. (2014). 34 Prinsip Etis Jurnalisme Lingkungan. Jakarta: Kepustakaan Populer Gramedia. Sugiyono. (2014). Memahami Penelitian Kualitatif. Bandung: Alfabeta.

Suhandang, Kustadi. (2004). Pengantar Jurnalistik, Seputar Organisasi, Produk, dan Kode Etik. Bandung: Nuansa.

Sumadiria, AS Haris. (2011). Jurnalistik Indonesia, Menulis Berita dan Feature, Panduan Praktis Jurnalis Profesional. Bandung: Remaja Rosdakarya.

http://jurnal.unpad.ac.id/kajian-jurnalisme 